\title{
Burden on Family Caregivers Caring for Patients with Cancer in Indonesia
}

\author{
Wenny Savitri' ${ }^{1}$, Suwarno ${ }^{2}$ \\ 1,2Department of Nursing, Universitas Jenderal Achmad Yani Yogyakarta.
}

\begin{tabular}{l} 
ARTICLE INFO \\
\hline Article history: \\
DOI: \\
$\underline{10.30595 / \text { pshms.v2i.226 }}$
\end{tabular}

Submitted:

December 6, 2021

Accepted:

January 21, 2022

Published:

January 26, 2022

\begin{abstract}
Cancer diagnosis has detrimental effects on patients' families since they have to take care of the patients, resulting in caregivers' burden. This study aimed to investigate the burden of family caregivers caring for cancer patients. A descriptive quantitative study was applied to 60 family caregivers of cancer patients in a government hospital in Yogyakarta. Data were gathered using sociodemographic and health-related instruments and Zarit Burden Interview, then analyzed by using descriptive statistics. The results showed all family caregivers expressed their feelings of the intensity of burden $(60 \%$ little or no burden, $36.7 \%$ mild-to-moderate, $3.3 \%$ moderate-to-severe), and none of them expressed severe burden. The majority were patients' children, married males, over 40 years old, and small family members living in the same house in a rural area. They went to high school or university, working in private sector, with monthly family income were below a minimum standard. They spent 1-6 hours per day for caregiving without experience in caring. They also did not have any chronic diseases, whom the majority of patients they were taking care of had third stadium of breast cancer without metastasis with chemotherapy. To conclude, most caregivers experienced little or no burden in caring for their family members with cancer.
\end{abstract}

Cancer in Indonesia; family burden; family caregiver; zarit burden interview

This work is licensed under a Creative Commons Attribution 4.0 International License.

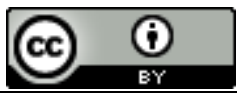

Corresponding Author:

Wenny Savitri,

Department of Nursing, Universitas Jenderal Achmad Yani Yogyakarta,

Jalan Ring Road Barat, Ambarketawang, Sleman, Yogyakarta, Indonesia

Email: wenny.savitri1@gmail.com

\section{INTRODUCTION}

Cancer becomes one of the biggest health issues in Indonesia since our country was the $8^{\text {th }}$ most prevalent country with cancer in South East Asia counting 136.2/100 thousand people. [1] In 2020, the data has inclined to 345.9/100 thousand people were diagnosed with cancer. [2]

As cancer treatments become advanced, more cancer patients are cared in home and families become more involved in care. Caregiving is perfoming a holistic care for someone who is in need of care, [3] in this case is cancer patients by their families. Family structure is extremely essential in Indonesian culture. Given the fact that homecare system is not well-developed in Indonesia, informal care is more common than formal care. Therefore, family members namely spouse, children, parents, or siblings or other relatives are responsible for caring cancer patients. [4]

Studies revealed that family members of cancer patients have many unmet needs as consequences of caregiving which affect quality of life. [5,6] It is a result from the nature of caregiving which is demanding and overwhelming leading to a stressful moments for caregivers [7] and is perceived as a burden to caregivers. [8] This condition leads to the descending of family caregiver quality of life. The study discloses a reciprocal relationship between the quality of life of the family caregiver and the patient. Therefore, it is essential to explore the family caregiver burden in caring for the cancer patient. [9] 
There have been very limited studies exploring burden on family caregivers of cancer patients in Indonesia, [4,10] and only applied on the family caregivers of advanced cancer patients [10] or using different assesment tools to assess the variable. [4] Hence, this current study aimed to assess the burden on family caregivers caring for cancer patients. The results may have practical importance to help designing nursing strategies for certain family caregivers with the risk of experiencing higher burden.

\section{RESEARCH METHOD}

The study was applied in a government hospital in Yogyakarta with 60 family caregivers of cancer patients, using sociodemographic and health related questionnaire and The Zarit Burden Interview (ZBI) to assess burden of family caregivers caring for cancer patients. Higher score of ZBI means higher burden expressed by the respondents. The data were analyzied using univariate statistical analysis.

\section{RESULT AND DISCUSSIONS}

The findings show the majority of family caregivers were male (53\%), 40 years old or more (55\%), married $(82 \%)$, had small family size $(92 \%)$, high school graduates $(43 \%)$, and worked in private sector $(30 \%)$ with family income more than minimum wege $(60 \%)$. Most of them were patients' children $(52 \%)$, living in rural area (87\%) and spending 1-6 hours a day (78\%) to take care of the patients with no experience in caring for patient with cancer $(88 \%)$ and without presence of chronic disease $(88 \%)$. On the other hand, the majority of the patients who were taken care were stage III cancer patients (43\%) without metastasis $(54 \%)$, and were treated with chemotherapy $(63 \%)$. The details of the respondents characteristics is displayed on table 1 while the family caregivers burden was mainly categorized as little or no burden (60\%) as seen on table 2.

Based on the respondents and patients' characteristics (table 1), the caregivers who were 40 years old or more, female, married, had small family size living in the same house, with no formal education, unemployed, had family income more than minimum wege, being child of the patient, lived in rural area, spent 1-6 hour a day for caring the patient, without caregiving cancer patient experience, and did not have chronic disease were portrayed having more burden for caregiving the patients as compared to others. The respondents also mentioned caring for cancer patients who were on stage III cancer with no presence of metastasis and undergone surgery therapy were giving them more burden.

Table 1. Family Caregivers and Patients' Characteristics and Mean Score of Burden (N=60)

\begin{tabular}{|c|c|c|c|c|}
\hline \multicolumn{2}{|c|}{ Family Caregivers' Characteristic } & \multirow{2}{*}{$\begin{array}{c}\mathbf{f} \\
27\end{array}$} & \multirow{2}{*}{$\begin{array}{c}\% \\
45 \%\end{array}$} & \multirow{2}{*}{$\begin{array}{c}\begin{array}{c}\text { Burden } \\
\text { (Mean } \\
\text { Score) }\end{array} \\
\\
17.04\end{array}$} \\
\hline Age & $<40$ years old & & & \\
\hline & $\geq 40$ years old & 33 & $55 \%$ & 19.30 \\
\hline \multirow[t]{2}{*}{ Sex } & Male & 32 & $53 \%$ & 17.69 \\
\hline & Female & 28 & $47 \%$ & 18.96 \\
\hline \multirow[t]{2}{*}{ Marital status } & Single & 11 & $18 \%$ & 18.25 \\
\hline & Married & 49 & $82 \%$ & 18.31 \\
\hline \multirow[t]{2}{*}{ Family size } & $2-6$ & 55 & $92 \%$ & 18.73 \\
\hline & $7-11$ & 5 & $8 \%$ & 13.40 \\
\hline \multirow[t]{4}{*}{$\begin{array}{l}\text { Education } \\
\text { level }\end{array}$} & No formal education & 1 & $2 \%$ & 21.00 \\
\hline & Secondary school & 11 & $18 \%$ & 17.45 \\
\hline & High school & 26 & $43 \%$ & 19.73 \\
\hline & Higher education & 22 & $37 \%$ & 17.77 \\
\hline Occupation & Home maker & 11 & $18 \%$ & 16.45 \\
\hline
\end{tabular}


Civil servant

Private sector employee

Farmer

Unemployed

Student

Retired

Family

income

$<$ Rp 1.842 .460

$\geq \operatorname{Rp} 1.842 .460$

Relation to patient

Spouse

Child

Parent

Others

Place of

residence

Rural

Urban

52

8

$87 \%$

$13 \%$

18.80

15.63

Duration of caregiving (hour/day)

1-6 hour

7-12 hour

13-18 hour

19-24 hour

Caregiving experience

Yes

No

Presence of chronic disease

Yes

No

7

53

19

41

47

4

2

7

7

4
18

$7 \%$

19.00

18.17

22.42

22.75

12.60

15.00

$10 \%$

17.33

18.92

$60 \%$

$22 \%$

$52 \%$

16.31

$10 \%$

20.61

$10 \quad 17 \%$

15.10

8

$78 \%$

$7 \%$

19.00

$3 \%$

16.50

$12 \%$

13.00

16.00

$32 \%$

$68 \%$

17.05

18.85

$12 \%$

$88 \%$

15.71

18.62

\section{Patients' clinical characteristics}

$\begin{array}{llccc}\text { Cancer stage } & \text { Stage I } & 9 & 15 \% & 16.00 \\ & \text { Stage II } & 8 & 13 \% & 15.63 \\ & \text { Stage III } & 26 & 43 \% & 22.19 \\ & \text { Stage IV } & 17 & 28 \% & 14.76 \\ & & & & \\ \text { Metastasis } & \text { Yes } & 6 & 10 \% & 14.83 \\ & \text { No } & 54 & 90 \% & 18.67 \\ \text { Cancer } & & & & \\ \text { treatment } & \text { Chemotherapy } & 38 & 63 \% & 18.58 \\ & \text { Surgery } & 2 & 3 \% & 28.00 \\ & \text { Chemotherapy and surgery } & 10 & 17 \% & 18.40\end{array}$




\begin{tabular}{lccc}
$\begin{array}{l}\text { Chemotherapy, surgery, and } \\
\text { radiotherapy }\end{array}$ & 8 & $13 \%$ & 16.50 \\
$\begin{array}{l}\text { Chemotherapy and } \\
\text { radiotheraphy }\end{array}$ & 2 & $3 \%$ & 9.50 \\
\hline
\end{tabular}

Table 2. Family Caregivers' Burden ( $\mathrm{N}=60)$

\begin{tabular}{|c|c|c|}
\hline Burden Category & $\mathrm{F}$ & $\%$ \\
\hline Little or no burden & 36 & $60 \%$ \\
\hline Mild to moderate & 22 & $37 \%$ \\
\hline Moderate to severe & 2 & $3 \%$ \\
\hline
\end{tabular}

Most of family caregivers perceived little or no burden (60\%) caring for cancer patients, and no one experienced severe burden.

Current study suggested most of family members only experienced little or no burden to take care of their families with cancer. It is consistent with a study in India where most of family caregivers of cancer patients reported no or minimal burden $(56.5 \%)$ and the rest was vary from mild to moderate to severe $(43.5 \%)$. [11]

It is contradictory with the findings from Werdani (2018) where $51.7 \%$ of the caregivers encountered moderate burden. [4] The family caregivers in that study mostly were female whilst in current study were male. [4] Previous studies stated that female sex were associated with higher caregiver burden. $[12,13,14]$ This is because of the unmet needs which were experienced more by female caregivers. [14]

More details regarding the mean score of burden might be affected by the family caregivers' characteristics. Respondents who were older got higher score of Zarit Burden Interview score, which means experiencing higher burden. It is in contrast with previous study which suggested younger age is associated with higher caregiver burden. [13] Adelman et al. (2014) explained that lack of choice of being a caregiver is one of risk factors for caregiver burden which might relate to our respondents since most of them were the patients' children. [12] To add more, the family member living in the same house with the patients is considered small (1-6 persons) which might also contribute to the lack of choice of family support and then leads to higher burden. [15] The study also suggested older age of family caregiver is related to higher burden which taking into account health problems as issues, even though in present study, $88 \%$ of respondents did not have chronic diseases.

The respondents who were married in current study perceived less burden as compared to singles. It is in accord to prior studies where being unmarried was associated with higher burden of "disrupted schedules". [13; 15] The time spent to take care of the patients interferes with the caregivers needs for their personal life to deal with stress.

In present study family caregivers who lived in rural area experienced higher burden than the ones lived in urban. It was advised living in rural area had more impact on finance and daily living. [16]

\section{CONSLUSION}

Nurses need to be aware with family caregivers who have characteristics older, female, living with small family size with the patient, child of the patient, rural area residency where most of them potentially going to experience more burden caring for cancer patients.

\section{Acknowledgements}

The researchers would like to express gratitude to the Ministry of Education Research and Technology of Republic Indonesia for funding this research project.

\section{REFERENCES}

[1] WHO. Latest global cancer data: Cancer burden rises to 18.1 million new cases and 9.6 million cancer deaths in 2018 [Online]. Available: https://www.uicc.org/new-global-cancer-data-globocan-2018

[2] WHO. 360 Indonesia Fact Sheets [Online]. Available: https://gco.iarc.fr/today/data/factsheets/populations/360-indonesia-fact-sheets.pdf

[3] M. Hermanns and B. Mastel-Smith, "Caregiving: A Qualitative Concept Analysis," The Qualitative Report, vol. 17, pp. 1-18, 2012.

[4] Y. D. W. Werdani, "Pengaruh Caregiving pada Pasien Kanker terhadap tingkat Caregiver Burden," Jurnal Ners dan Kebidanan, vol. 5, pp. 249-256, 2018. 
[5] N. Friðriksdóttir, P. r. Sævarsdóttir, S. s. i. r. Halfdánardóttir, A. s. Jónsdóttir, H. Magnúsdóttir, K. n. 1. r. ÓLafsdóTtir, et al., "Family members of cancer patients: Needs, quality of life and symptoms of anxiety and depression," Acta Oncologica, vol. 50, pp. 252-258, 2011.

[6] N. Turkoglu and D. Kilic, "Effects of Care Burdens of Caregivers of Cancer Patients on their Quality of Life," Asian Pacific Journal of Cancer Prevention, vol. 13, pp. 4141-4145, 2012.

[7] C. Effendy, M. Vernooij-Dassen, S. Setiyarini, M. S. Kristanti, S. Tejawinata, K. Vissers, et al., "Family caregivers' involvement in caring for a hospitalized patient with cancer and their quality of life in a country with strong family bonds," Psycho-Oncology, vol. 24, pp. 585-591, 2014.

[8] B. A. Given, C. W. Given, and S. Kozachik, "Family Support in Advanced Cancer," CA Cancer J Clin, vol. 51, pp. 213-231, 2001.

[9] S. Y. Rha, Y. Park, S. K. Song, C. E. Lee, and J. Lee, "Caregiving burden and the quality of life of family caregivers of cancer patients: the relationship and correlates," European Journal of Cancer Care, vol. xxx, pp. 1-7, 2015.

[10] I. W. W. Sari, S. Warsini, and C. Effendy, "Burden among family caregivers of advanced-cancer patients in Indonesia," Belitung Nursing Journal, vol. 4, pp. 295-303, 2018.

[11] S. Lukhmana, S. Bhasin, P. Chhabra, and M. Bhatia, "Family caregivers' burden: A hospital based study in 2010 among cancer patients from Delhi," Indian J Cancer, vol. 52, pp. 146-51, 2015.

[12] R. D. Adelman, L. L. Tmanova, D. Delgado, S. Dion, and M. S. Lachs, "Caregiver burden: a clinical review," JAMA, vol. 311, pp. 1052-60, 2014.

[13] L. Ge and S. Z. Mordiffi, "Factors Associated With Higher Caregiver Burden Among Family Caregivers of Elderly Cancer Patients: A Systematic Review," Cancer Nursing, vol. 00, pp. 1-8, 2016.

[14] J. Perz, J. M. Ussher, P. Butow, and G. Wain, "Gender differences in cancer carer psychological distress: an analysis of moderators and mediators," European Journal of Cancer Care, vol. 20, pp. 610-619, 2011.

[15] S.-J. Yoon, J.-S. Kim, J.-G. Jung, S.-S. Kim, and S. Kim, "Modifiable factors associated with caregiver burden among family caregivers of terminally ill Korean cancer patients," Support Cancer Care, vol. 22, pp. 1243-1250, 2014.

[16] K. Ehrlich, A.-M. Bostrom, M. Mazaheri, K. Heikkila, and A. Emami, "Family caregivers' assessments of caring for a relative with dementia: a comparison of urban and rural areas," Older People Nursing, vol. 10, pp. 27-37, 2014. 